\title{
An Exploration of the History of Vocational Education in Hong Kong
}

\author{
Leung Yung, Y. Liang \\ Sun Yat-sen University, Guangzhou, China \\ TSE Wai-chi, Vivian \\ The University of Hong Kong, Hong Kong
}

\begin{abstract}
Vocational education in Hong Kong has over 150 years of history, which can be classified into four stages-Stage one: The inception of Hong Kong-A period mainly focusing on the provision of technical, commercial, and seamen training. The first technical and commerce school was established in 1864 by the Church; Stage two: At the end of the Sino-Japanese War-A period when a great number of vocational schools were started, reflecting the prosperous development of technical and business education; Stage three: In the early 1990s-A period when Hong Kong had been experiencing a decline in industries. Many vocational schools were transformed into grammar schools, resulting in a sharp decline in their numbers; and Stage four: The beginning of the 21st century-A period when vocational schools had been regaining their momentum through successful implementation of qualifications framework courses and active collaboration with enterprises in order to cultivate competitive talents for different professions, receiving society's recognition.
\end{abstract}

Keywords: Hong Kong, vocational education, education history, historical changes

\section{Introduction}

In order to explore the history of vocational education in Hong Kong, one may trace back to the apprenticeship system adopted by Queen Elizabeth I in the 16th century, as well as the onset of the industrial revolution in the 18th century. During these times, large numbers of workers were urgently needed. To cater for this demand, vocational schools were established by the then Hong Kong Government. In 1842, Hong Kong became a British colony and its harbour was opened up for trade. Every effort was made to develop commerce, industry, and seamen training. Schools at that time were usually run by the Church, vocational schools (hereinafter referred to as "trade schools") were no exception. The first trade school was set up on Hong Kong Island in 1864. Not until 1933 did the British Hong Kong Government run the first government-run trade school. When the Sino-Japanese war was over, Hong Kong's commerce and industry was booming. A high concentration of vocational schools could be seen in the territory. In the early 1990s, a substantial number of trade schools were transformed to grammar schools. In the 21st century, Hong Kong's economy has been experiencing a structural change. Vocational schools actively collaborated with such industries as business, finance, service sector, creative design, and technology for cultivating competitive professionals. This paper

Leung Yung, Y. Liang, Ph.D. candidate, Department of History, Sun Yat-sen University.

TSE Wai-chi, Vivian, Education Team, School of Professional and Continuing Education, The University of Hong Kong. 
mainly explores the stages in the development of vocational education in Hong Kong. The four stages are the inception of Hong Kong, the post-war period, the early 1990s, and the 21 st century.

\section{Early Period of the Inception of Hong Kong: The Birth of Vocational Schools}

\section{Vocational School Established by the Church}

In the early period, Hong Kong was only a fishing port. Private schools ( $\mathrm{Si} \mathrm{Shu}$ ) education was popular in local villages. Students were required to learn "The Four Books and the Five Classics". In 1842, the Qing dynasty of China signed the Treaty of Nanjing, agreeing to cede Hong Kong Island to the United Kingdom. Since then, the Victoria Harbour had been developed and positioned for industry and commerce. At that time, many western missionaries came to Hong Kong to carry out missionary activities through setting up churches and schools. For example, the "Reformatory" on Hong Kong West was established in 1964. It became the first missionary base for the provision of formal technical education. At first, some 60 students were admitted. Most of them were teenagers released from prisons, as well as orphans found sleeping on the streets. This training centre also provided childcare services for parents in the district. Children were taught to undertake courses that are craft-oriented, such as leather work, woodwork, textile, and sewing, etc. Besides, training in planting, husbandry, marketing, moving stones, clearing land for cultivation, slope stabilization, and wall building, etc. (Xia, 1998) were also provided for these underprivileged children. Through receiving vocational training, they could acquire trade skills which would enable them to earn a living. At that time, Marcus Leong (Xia, 2000), a Chinese priest, was the director of the Reformatory. Students and the locals all called him "Father Leung". He was a subordinate of Father Ko. Father Leung was the first Chinese who promoted vocational training. At the training centre, Father Leung made earnest efforts in promoting trade and commerce education, setting up work factories, providing food and accommodation, as well as enrolling poor children living in the Central and Western District, until he passed away in 1904. Father Leung can thus be called "The Father of Vocational Education in Hong Kong". Thereafter, managed by the De La Salle Brothers in 1875, the "Reformatory" was renamed as "Western District Training Centre". It was then operated by the Maryknoll Catholic Foreign Mission Society of America in 1921, followed by the Salesians of Don Bosco in 1927. Its name was finally renamed as the "Saint Louis Technical and Craft College".

In 1935, some craft subjects, such as woodwork, leather craft, sewing, and machinery works were integrated into the curriculum of Aberdeen Trade School (the predecessor of "Aberdeen Technical School") to which capital was raised through donations from rich merchants. In the following year, the "Aberdeen Trade School" was transformed to a grammar school and had its name changed to the "Saint Louis School".

\section{Vocational Schools Established by the Government}

The first government-aided full-time vocational school was called the "Junior Technical School", which was established by the British Hong Kong Government in 1993. Three years later, the first taught Technical Institute was called the "Government Trade School" with its campus located on Wood Road in Wanchai. It was a three-storey high Victorian architecture commonly referred to as the "Red Brick House", offering a range of vocational courses, such as marine navigation, wireless operations, mechanical engineering, and construction. 


\section{Post-War Period: A High Concentration of Vocational Schools}

\section{Vocational Education Courses Run by Trade Unions and Universities}

A large number of vocational schools had once ceased operation during the Japanese invasion. Following the end of the Sino-Japanese War in 1945, a civil war sparked between the Kuomintang and the Chinese Communist Party. Many refugees flocked to Hong Kong and brought into the territory a huge amount of capital, skills, and expertise. Due to the rapid development of Hong Kong's manufacturing industries, i.e., textile, garment, plastics, printing, toys, watches and clocks, and electronics, huge amount of goods and resources were shipped and transferred to the mainland and overseas. Thus, Hong Kong became an international re-export trade port (or entrepot).

Because of the rapid developments in its industries and harbor trade, there was a large demand for trained workforce. In view of this, Brook Antony Bernacchi OBE, QC, and JP, a British Barrister, established the "Stanley Children's Camp cum Hong Kong Sea School" (now referred to as the "Hong Kong Sea School") in 1946 which specialized in the provision of seamen training. Free meals, accommodation, and education were provided for the homeless children. In the same year, the first school catering for workers' children was established by the Education Advancement Society for Workers (EASW)' Children in Hong Kong and Kowloon (later renamed as the "EASW in Hong Kong and Kowloon" or "EASW"), a group formed by several trade unions. In the following year, EASW set up the first batch of evening schools, namely, the "Sham Shui Po Female Textile Workers' Night School" and the "To Kwa Wan Female Textile Workers' Night School" to cater for workers in Hong Kong. Later on, the "Metal Workers' Night School" and the "Shau Kei Wan Workers' Night School" were established. In 1957, the "Mongkok Workers' Night School" was founded. Technical training courses, such as electronics and electricity, lathing and grinding, automobile repairs had been provided (Hong Kong Workers' School, 2006). In the same year, the University of Hong Kong (HKU)'s Department of Extra Mural Studies (DEMS) was established. Vocational courses for Building Construction, Economics, and Company Secretary Training were provided, so that people from all walks of life would have the opportunities for personal, professional and career advancement in their spare time (The Dept., 1957). DEMS was the first continuing education department operated by a university in Hong Kong. Thereafter, it was renamed as the "HKU School of Professional and Continuing Education" (HKU SPACE).

\section{Establishment of "Technical College", "Technical Secondary Schools", and "Prevocational Schools" by the Hong Kong Government}

The "Government Trade School" was renamed as the "Hong Kong Technical College" (referred to as the "Technical College") and reopened in 1947 by the then Hong Kong Government. Courses, such as shipbuilding, repairing, and navigation technology, were available. In the same year, the "Junior Technical School" was moved to the "Red Brick House" under the operation arm of the "Technical College". In 1957, the "Technical College" was granted land by the government for the building of a campus in Hung Hom. In 1972, the status of "Technical College" was upgraded to the "Hong Kong Polytechnic", and finally, granted a university status. It is now called "The Hong Kong Polytechnic University".

The "Junior Technical School" was renamed as the "Victoria Technical School". Having received a generous donation by the late Sir Tang Shiu Kin CBE, KStJ, and JP in 1979, the "Victoria Technical School" moved out of the "Red Brick House" and renamed as the "Tang Shiu Kin Victoria Technical School". Between the 1960s and 1970s, the Hong Kong Government approved the opening of a number of technical secondary 
schools (referred to as "Technical Secondary-TSs") and pre-vocational schools (referred to as "pre-vocational-pre-vocational") in order to assist primary six school leavers who had failed in the "Secondary School Entrance Exam" to acquire a trade skill. The total number of vocational schools exceeded 30 , among which 10-odd were run by the Government, some by the Church, charity organisations, as well as business organisations.

On the other hand, in order to improve Hong Kong products' quality, the Government set up the "Industry Training Advisory Committees (ITACs)"- a committee responsible for the future planning of Hong Kong's Industry Training. In addition, vocational training was extended to the disabled people. "Skills Centre" (nowadays referred to as the "Shine Skills Centres") was set up in 1968. At that time, the first technical institute called the "Morrison Hill Technical Institute" was established by the Government at the "Red Brick House". In 1973, the Hong Kong Training Council was established to replace the "Industry Training Advisory Committees (ITACs)". Its role was to design training programmes related to the construction and clothing industry. In accordance with the Industrial Training Ordinance (Legislative Council, 1975), the Clothing Industry Training Authority and the Construction Industry Training Authority were established in 1975 respectively. The "White Paper on Secondary Education for Hong Kong in the Next 10 Years" (Board of Education, 1974) was published, the aim of which was to take active steps to promote the development of technical institutes. Hence, in the four years following 1975, technical institutes had been established one after another, namely, the "Kwai Chung Technical Institute", the "Kwun Tong Technical Institute", the "Haking Wong Technical Institute", and the "Lee Wai Lee Technical Institute". After the establishment of these technical institutes, the "Apprenticeship Ordinance" was passed, which stipulated that employers of designated trades must enter into a contract of apprenticeship with young staff aged between 14 and 19 years old, and recommend them for admission into one of these technical institutes to pursue a course related to his/her trade. In 1978, the system for a nine-year free and universal education (also commonly referred as "nine-year compulsory education") was implemented by the Hong Kong Government. A batch of students who could not adapt well to the grammar school system had emerged. In view of this, skills training schools and practical schools were established by the education department (ED). The first practical school was transformed from "The Hong Kong Sea School” which was originally designed for seaman training. Some students enrolled in this practical school, mainly because they were attracted by its dormitory facilities. This period is regarded as the booming stage of Hong Kong's vocational education.

\section{The 1990s: Popularity Dwindled From Boom to Bust-Transformation of Vocational Schools to Grammar Schools}

\section{Establishment of the Vocational Training Council by the Hong Kong Government}

Established in 1982 by the Hong Kong Government, the "Vocational Training Council" (abbreviated as "VTC") was set up in accordance with the "Vocational Training Council Ordinance" (Legislative Council, 1982). The VTC is a statutory body which specialises in handling and coordinating industrial training affairs. Also, the technical education and training department was set up. Its major role was to execute VTC's decisions. In 1984, the first development centre, namely, the Management Development Centre of Hong Kong "MDCHK" was established with its first centre called the "Plastics Training Centre". In subsequent years, training centres targeting at various professions and industries, such as textile, automobile, soldering, electrical engineering, hospitality, gas and fuel, electronic data processing, insurance, precision tools' manufacturing, jewellery, 
banking, marine, application-specific integrated circuit (ASIC) design, wholesale and retail, export and import trade, etc. had been set up accordingly (Vocational Training Council, 2007). Moreover, more Technical Institutes were opened in Tuen Mun, Shatin and Chai Wan, as well as the Hong Kong Institute of Technology in Tsing Yi. In 1999, an integration policy was launched by the VTC to merge all Technical Institutes (TIs) and Institute of Technology into the "Hong Kong Institutes of Vocational Education" (commonly referred to an abbreviated as "IVE").

\section{Transformation of Vocational Schools to Grammar Schools}

Vocational education in Hong Kong had experienced a dramatic change in the 1990s. Relocation of Hong Kong's manufacturing industries to the mainland resulted in a structural change in Hong Kong's economy. Technical and craft education was no longer attracting students. With a view to upgrade employees' skills, the "Employees Retraining Ordinance" was adopted by the Legislative Council to set up the "Employees Retraining Board". With respect to secondary education, on the one hand, places in traditional grammar schools were adequate. On the other hand, both technical secondary schools and prevocational schools were not parents' preference, simply because of the social norm. Parents believed that students in these schools were generally lagging behind others in terms of their poor academic and bad conduct, in addition to the negative effects of the labeling of these schools as Band 5 schools (nowadays, as Band 3 schools).

Since the number of students became lesser and lesser, technical secondary schools and prevocational schools started recruiting new cohorts of Secondary 6 students who wished to attend the Hong Kong Advanced Level Exam (matriculation exam). This resulted in blurring the distinction between vocational schools and traditional grammar schools. A research conducted in 1996 by the then education department revealed that "art, practical and craft and technology subjects" accounted for approximately 25-30\% of technical secondary schools' curriculum-A percentage, i.e., 15-20\%, which was very close to that of traditional grammar schools (Research Office, Legislative Council Secretariat, 2015). In order to address this problem, the government reassessed the functional roles of vocational schools in the territory.

In 1997, Hong Kong handed over her sovereignty to China. During this time, vocational training and education had been undergoing a reform. The "Review of Prevocational and Secondary Technical Education" was presented by the Hong Kong Education Department, stating that the curriculum adopted by technical schools and traditional grammar schools in Hong Kong were very similar content-wise. Some technical secondary schools intended to cross out the word "technical" in their schools' names. The review suggested that these technical secondary schools may apply for a change of their school's registration names. As a result, the wordings "technical secondary schools" were basically not required to be shown explicitly. To address the effect of negative labelling, wordings like "prevocational" or "technical" appeared in the school names were deleted eventually. For example, the "Marden Foundation Caritas Prevocational School" was changed to the "Caritas Chai Wan Marden Foundation Secondary School", and the "Shau Kei Wan Government Technical Secondary School" was changed to the "Shau Kei Wan East Government Secondary School". Only a handful of technical secondary schools, i.e., "Kowloon Technical School" and "Aberdeen Technical School", kept using their entire school names. Furthermore, continuing its justification for "de-labelling", the Education Bureau facilitated the integration of technical training and practical schools into the realm of mainstream secondary schools. 


\section{From 2000 Till Present: Launching of Quality Framework (QF) Courses Through Cross-Industry Collaboration}

\section{Emphasis on Practicability and Fun}

With the advent of the 21st century, many students in Hong Kong have lost interest in traditional education provided by grammar schools. According to a recent statistical figure released by the government of the Hong Kong Special Administrative Region (SAR), the number of "non-engaged" teenagers aged 15 to 19 has raised drastically to approximately 19,000, reflecting the seriousness of dropouts and unemployment issues (Board editor A\&B, 1999; Press Release, 2001). To respond to the problem, the Youth College, a member of VTC Group, was set up in 2004, offering an interactive learning environment for youths who had attained Secondary 3. Studying with the the Youth College, this group of youths would acquire knowledge and skills for further studies and employment.

Under the umbrella of the VTC group, Youth Colleges have launched various types of career-oriented programmes in response to the needs of the local labour market. These programmes have been quite popular among teenagers and parents. Within 10 years of the establishment of the Youth College, a total number of Youth Colleges have expanded to eight, spreading across the Hong Kong Island, Kowloon, and the New Territories. Nearly 20 professional programmes have been launched, namely, commerce, information technology, watch and clock technology, cosmetics, physical fitness and exercise, automobile technology, aircraft maintenance, electrical engineering, construction, mechanical engineering, building services engineering, print media, jewellery arts and design, fashion textile design and merchandising, digital electronics and technology, and computer-aided product engineering, etc. Moreover, various member institutions were set up, so that a broad spectrum of programmes was provided, a wide range of industries were covered, and students with different backgrounds and abilities were catered for.

These institutions were, namely, the Hong Kong Design Institute (HKDI), School of Business and Information Systems (SBI), Chinese Culinary Institute (CCI), International Culinary Institute (ICI), Hotel and Tourism Institute (HTI), and 18 training and development centres. Moreover, the Technological and Higher Education Institute of Hong Kong (THEi) was set up to provide career-oriented degree programmes. At present, VTC is the largest vocational and professional education and training provider in Hong Kong.

\section{Developing Vocational Courses Under the QF}

With the aim to enhance the recognition of vocational education curriculum, the Hong Kong SAR Government promulgated the "Accreditation of Academic and Vocational Qualifications Ordinance" in 2007 and established the "Hong Kong Council for Accreditation of Academic and Vocational Qualifications" (Accreditation Council), formerly known as the "Hong Kong Council for Academic Accreditation". In the following year, a seven-tier QF was officially launched. To cope with the commission of QF, the Education Bureau (EDB) announced the establishment of the "Training Advisory Committee" (Advisory Committee) for various sectors. The Advisory Committee comprises employers and employees of respective sectors, as well as representatives of related professional bodies, thereby, ensuring the status of its representation. In 2009, the EDB assisted in the establishment of Advisory Committees for 12 sectors. These Advisory Committees assisted relevant sectors to draft the Specification of Competency Standards (SCSs), which set out the skills, knowledge, and outcome standards required of employees in different functional areas of the respective sectors, and provided a basis for course providers to design training courses to meet the needs of various sectors. 
Hence, course providers must design appropriate training courses based on the standards and requirements of individual industries. Having been vetted by the Hong Kong Council for Accreditation of Academic and Vocational Qualifications (HKCAAVQ), such courses would then be included in the list of QF Accredited Programmes. Today, vocational education is not only recognized by the society in Hong Kong but favored by students and parents. Students may choose a suitable vocational course based on his/her interest. Some courses also allow students to undergo internship at relevant enterprises or organizations. At present, apart from courses offered by the VTC, full-time and part-time vocational courses are also offered by universities in Hong Kong, such as HKU's School of Professional and Continuing Education (HKU SPACE), CityU's School of Continuing and Professional Education (CityU SCOPE), Chinese University's School of Continuing and Professional Studies (CUSCS), and Lingnan University's Lingnan Institute of Further Education (LIFE). Furthermore, religious groups, such as the Caritas Hong Kong, the Chinese Young Men's Christian Association of Hong Kong (YMCA), the Hong Kong Young Women Christian Association (YWCA), the Christian Action, and the St. James' Settlement also jumped on the bandwagon in the provision of vocational courses. In addition, vocational courses are also offered by the Hong Kong Federation of Trade Unions Spare Time Study Centre (HKFTUSTSC), and the Hong Kong College of Technology (formerly called "the Mongkok Workers' Night School”), etc. Vocational education courses are literally available in Hong Kong territory-wide. Learners may choose to pursue continuing studies and lifelong learning courses which suit their needs based on the seven-tier qualifications framework.

\section{Conclusion}

The development of vocational education in Hong Kong has experienced a complicated process of rise and fall, prosperity and decline. Vocational education has followed the pace of economic development through introducing a range of vocation courses to cater for the labour market needs. The success factors of vocational education are largely based on how well vocational schools are managed and operated, how well these courses address the needs of the labour market and adhere to the manpower needs for cultivating competitive talents for various professions.

Therefore, for a sustainable development of vocational education in Hong Kong, every effort should be made to ensure diversity in courses/programmes delivery, timely awareness, and prediction of both international and local demands of the labour markets, the continual updating and upgrading of knowledge, skills, technical and technological know-hows, emphasising on fostering generic skills for cultivating the spirit of life-long learning, respect, and enjoyment at one's work. Thus, a creative and competitive workforce will be nurtured for promoting the economic development of Hong Kong.

\section{References}

Board editor A. (1999, May 29). Rise in youth jobless rate spurs extra vocational training plan. Hong Kong: Hong Kong Standard. Board editor B. (1999, August 26). Teenagers to get help in job hunt. Hong Kong: Hong Kong Standard.

Board of Education. (1974, October). White paper on secondary education in Hong Kong over the next decade (Para. 2.5). Hong Kong: Government Printer.

Hong Kong Workers' School. (2006). The 60th anniversary of Hong Kong Workers' School (1946-2006). Hong Kong Workers' School Educational Organisation.

Legislative Council. (1975). Industrial training (construction industry) ordinance (Cap. 317); Industrial training (clothing industry) ordinance (Cap. 318). Hong Kong e-Legislation. Retrieved from https://www.elegislation.gov.hk/index/chapternumber?QS_CAP_NO=\%E5\%B7\%A5\%E6\%A5\%AD\%E8\%A8\%93\%E7\%B 7\%B4(\%E5\%BB\%BA\%E9\%80\%A0\%E6\%A5\%AD)\%E6\%A2\%9D\%E4\%BE\%8B\&p0=1\&TYPE=1\&TYPE=2\&TYPE=3 \&LANGUAGE=E\&TITLE=INDUSTRIAL\%20TRAINING\%20(CLOTHING\%20INDUSTRY)\%20ORDINANCE 
Legislative Council. (1982). Vocational training council ordinance (Cap. 1130). Hong Kong e-Legislation. Retrieved from https:/www.elegislation.gov.hk/index/chapternumber?QS_CAP_NO=VOCATIONAL\%20TRAINING\%20COUNCIL\%20 ORDINANCE\&p0=1\&TYPE=1\&TYPE=2\&TYPE=3\&LANGUAGE=E\&TITLE=Vocational\%20Training\%20Council\%20 Ordinance

Press Release. (2001, November 30). Labour Department launched pilot programmes to enhance youth employment. Government Information. Hong Kong Government News.

Research Office, Legislative Council Secretariat. (2015). Review of development of vocational education in Hong Kong. Retrieved fromhttp://www.legco.gov.hk/research-publications/english/1415in15-review-of-development-of-vocational-education-inhong-kong-20150813-e.pdf

The Dept. (1957). Department of extra-mural studies: Programme of extra-mural courses. Hong Kong: University of Hong Kong. Vocational Training Council. (2007). VTC 25th anniversary commemorative Book. Hong Kong: Vocational Training Council.

Xia, Q. L. (1998). The foundation of the Catholic mission in Hong Kong 1841-1894 (Doctoral dissertation, Hong Kong Doctoral Dissertations).

Xia, Q. L. (2000). The 19th century Hong Kong Catholic Chinese Missionaries. Spiritual Thinking, 47(11), 73-82. (in Chinese) 